\title{
Risk factors in acute respiratory distress syndrome among children with cancer in Brazilian Amazon: An observational study
}

Fatores de risco na síndrome do desconforto respiratório agudo em crianças com câncer na

Amazônia brasileira: Estudo observacional

Factores de riesgo en el síndrome de dificultad respiratoria aguda en niños con cáncer en la

Amazonía brasileña: Estudio observacional

Received: 06/30/2021 | Reviewed: 07/04/2021 | Accept: 07/22/2021 | Published: 07/29/2021

\begin{tabular}{|c|}
\hline Emmerson Carlos Franco de Farias \\
\hline ORCID: https://orcid.org/0000-0001-8627-5694 \\
\hline Fundação Santa Casa de Misericórdia do Pará, Brazil \\
\hline E-mail: emmersonfariasbrandynew@gmail.com \\
\hline Manoel Jaime Castro Pavão Júnior \\
\hline ORCID: https://orcid.org/0000-0001-5685-9947 \\
\hline Fundação Santa Casa de Misericórdia do Pará, Brazil \\
\hline E-mail: manoelpavaojr@gmail.com \\
\hline Luana Guimarães Dias \\
\hline ORCID: https://orcid.org/0000-0002-5092-2324 \\
\hline $\begin{array}{r}\text { Fundação Santa Casa de Misericórdia do Pará, Brazil } \\
\text { E-mail:luanagdias@ @otmail.com }\end{array}$ \\
\hline Emanuele Rocha da Silva \\
\hline ORCID: https://orcid.org/0000-0002-9109-4158 \\
\hline Universidade Federal do Pará, Brazil \\
\hline E-mail: emanueleersilva@gmail.com \\
\hline Rodrigo Santiago Barbosa Rocha \\
\hline ORCID: https://orcid.org/0000-0001-5964-946X \\
\hline Universidade do Estado do Pará, Brazil \\
\hline E-mail:rodrigo.santiago.rocha@uepa.br \\
\hline Katiane da Costa Cunha \\
\hline ORCID: https://orcid.org/0000-0001-5361-5090 \\
\hline Universidade do Estado do Pará, Brazil \\
\hline E-mail:katiane.cunha@uepa.br \\
\hline Aurimery Gomes Chermont \\
\hline ORCID: https://orcid.org/0000-0001-8715-3576 \\
\hline $\begin{array}{l}\text { Universidade Federal do Pará, Brazil } \\
\text { E-mail: agchermont@gmail.com }\end{array}$ \\
\hline \\
\hline
\end{tabular}

\begin{abstract}
This study was undertaken to determine the incidence and potential risk factors associated with Acute Respiratory Distress Syndrome (ARDS) in pediatric oncologic patients undergoing invasive mechanical ventilation and the association between mortality risk factors and ARDS. Retrospective cohort study was conducted using data analysis of patients on admission to the PICU, that were submitted to invasive mechanical ventilation for over 24 hours. Shapiro-Wilk test and bivariate analysis within the group exposed to ARDS and the one not exposed, as well as Fisher's, Wilks G, chi-square tests, and Poisson logistic regression were applied, with significant variables $\mathrm{p}<0.05$ and $95 \%$ CI. From que 181 pediatric cancer patients included in the study, $69.06 \%$ had ARDS, with $48 \%$ leukemia, $58.4 \%$ pneumonia, $60.8 \%$ febrile neutropenia, and $76.1 \%$ were in the maintenance chemotherapy phase; $\mathrm{pH}$ expressed higher relation with ARDS outcome and mortality. These data are important as this is one of the first studies carried out on ARDS in the pediatric cancer population in the North of Brazil, but further research is needed to better correlate risk factors and acute respiratory distress syndrome on such population.
\end{abstract}

Keywords: Respiratory distress syndrome; Epidemiology; Mechanical ventilation; Neoplasms.

\section{Resumo}

O presente estudo teve por objetivo determinar a incidência e os potenciais fatores de risco associados à Síndrome do Desconforto Respiratório Agudo (SDRA) em pacientes oncológicos pediátricos submetidos a Ventilação Mecânica Invasiva (VMI) e avaliar a possível associação entre fatores de risco para mortalidade e a SDRA. Foi conduzido um estudo de coorte retrospectiva, com análise dos dados de admissão na Unidade de Terapia Intensiva Pediátrica (UTIP) de pacientes oncológicos pediátricos submetidos à VMI por mais de 24 horas. Após aplicação do teste de Shapiro- 
Wilk, foi realizada análise bivariada entre o grupo com SDRA e o sem SDRA, para avaliar a associação entre o grupo exposto e as variáveis epidemiológicas, gasométricas, ventilatórias e clínicas. Foram utilizados os testes Exato de Fisher, Teste Wilks G e o Qui-quadrado. Aplicou-se ainda a regressão logística de Poisson. As variáveis significantes tiveram p<0.05 e IC 95\%. Dentre os 181 pacientes pediátricos portadores de câncer incluídos no estudo, a incidência de SDRA foi de $69,06 \%$, sendo que dentre esses $48 \%$ tinham leucemia, 58,4\% apresentavam pneumonia, $60,8 \%$ neutropenia febril e 76,1\% estavam na fase de manutenção da quimioterapia, tendo o pH mostrado mais relação com o desfecho SDRA e mortalidade. Esses dados são importantes visto que se trata de um dos primeiros estudos realizados acerca de SDRA na população oncológica infantil na região Norte do Brasil, porém tornam-se necessários mais trabalhos para melhor correlacionar os fatores de risco e a síndrome de desconforto respiratório agudo na população oncológica pediátrica.

Palavras-chave: Síndrome do desconforto respiratório; Epidemiologia; Neoplasias.

\section{Resumen}

Este estudio tuvo como objetivo determinar la incidencia y los posibles factores de riesgo asociados con el síndrome de dificultad respiratoria aguda (SDRA) en pacientes pediátricos con cáncer sometidos a ventilación mecánica invasiva (VMI) y evaluar la posible asociación entre los factores de riesgo de mortalidad y SDRA. Se realizó un estudio de cohorte retrospectivo, con análisis de los datos de ingreso a la Unidad de Cuidados Intensivos Pediátricos (UCIP) de pacientes pediátricos con cáncer sometidos a VMI durante más de 24 horas. Tras aplicar la prueba de Shapiro-Wilk, se realizó un análisis bivariado entre el grupo con y sin SDRA, para evaluar la asociación entre el grupo expuesto y las variables epidemiológicas, gasométricas, ventilatorias y clínicas. Se utilizó la prueba exacta de Fisher, la prueba $\mathrm{G}$ de Wilks y la chi-cuadrado. También se aplicó regresión logística de veneno. Las variables significativas tuvieron $\mathrm{p}<0,05$ e IC del $95 \%$. Entre los 181 pacientes pediátricos con cáncer incluidos en el estudio, la incidencia de SDRA fue del $69,06 \%$, de los cuales el $48 \%$ tenía leucemia, el 58,4\% tenía neumonía, el $60,8 \%$ neutropenia febril y el $76,1 \%$ estaban en la fase de mantenimiento de la quimioterapia, con pH que mostraba más relación con el SDRA y el resultado de la mortalidad. Estos datos son importantes ya que este es uno de los primeros estudios realizados sobre SDRA en la población infantil con cáncer en el norte de Brasil, pero se necesitan más trabajos para correlacionar mejor los factores de riesgo y el síndrome de dificultad respiratoria aguda en la población oncológica pediátrica.

Palabras clave: Síndrome de dificultad respiratoria; Epidemiologia; Respiración artificial, Neoplasias.

\section{Introduction}

For the five last decades, advances in the development and use of chemotherapy led to better survival of pediatric cancer patients and to the consequently greater need for intensive support (Beringer et al., 2017). Acute respiratory failure is a common reason for admission to the Pediatric Intensive Care Unit (PICU) in cancer patients, while Acute Respiratory Distress Syndrome (ARDS) represents the most severe form of acute lung injury and is characterized by infiltration of alveolar leukocytes and lung protein-rich edema (Khemani et al., 2015; Su et al., 2013).

The epidemiology and the impact on mortality and morbidity are not similar between general and oncology pediatric patients, however, during the last decade there have been few publications on ARDS in severely ill oncological children, and the majority of the published ones were developed in high socioeconomic status countries, after bone marrow transplantation (Zinter et al., 2018; Azoulay et al., 2010; Tamburro et al., 2008).

Such an information gap underestimates the relationship between ARDS and worse clinical outcomes in children from limited resources settings, such as the northern region of Brazil. Based on this, the objectives of this study were: (1) to determine the incidence and potential risk factors associated with ARDS in patients undergoing Invasive Mechanical Ventilation (IMV); (2) to evaluate the possible association between mortality risk factors and ARDS.

\section{Methodology}

The present study follows the precepts established in the number 466/12 Resolution of the Brazilian National Health Council and had been approved on 2018/06/06 by the Research Ethics Committee of the Santa Casa de Misericórdia do Pará, based on advisory opinion 2,695,187, Ethical Appreciation Presentation Certificate: 89172218.8.0000.5171 
A historical cohort study was conducted from January 2016 to June 2017, using data analysis of patients admitted to the PICU of Children's Oncologic Hospital Octávio Lobo in Belém, Pará state, during the period. It represents the only children exclusive oncology hospital in the Northern region of Brazil and holds exclusively Unified Health System's demand, service offered with 90 beds destined to wards and emergency care, and 10 beds to intensive care (Pereira, A. S. et al., 2018).

The study is part of a larger one entitled "Intensive support in a children's oncology referral hospital". Inclusion criteria were hospitalizated patients who underwent IMV for over 24 hours; and exclusion criteria were intubated patients for other reasons than critical illness, such as procedure, long-term patients in the PICU (over 90 days), patients admitted for cardiorespiratory arrest who did not reach vital sign stability in 24 hours, those in palliative care and the ones in order to donot-resuscitate and in brain death.

From this initial procedure, an active search was performed in the electronic medical records of the included patients to obtain the clinical, ventilatory, and gasometric features of the population. Independent variables were collected on admission (worst values on the first 24 hours) and divided into (1) sociodemographic, (2) clinics, (3) ventilatory, and (4) blood gas measurements. The outcome variable considered was 28 -day mortality.

Data collection was carried out from the unit's database by filling in sociodemographic data that included the patient's name, record, date of birth, date of admission and release, sex, age in months, weight, and height. The patients' age was considered in full months, later classified according to the age range (Brasil, 2012).

The following clinical variables were analyzed: reason for hospitalization, IMV indication, type of neoplasm according to the International Classification of Cancer in Childhood-3rd edition (CICI-3) (Steliarova-Foucher et al., 2005), chemotherapy’s need, phase, and its length, the presence of febrile neutropenia (Baden et al., 2016), presence of sepsis, septic shock and pneumonia - according to the current pediatric definitions - (ANVISA, 2017; Goldstein et al., 2005), number of days spent in the PICU, time on IMV and days free from IMV (defined as the number of days alive and without respiratory assistance, from admission until the 28th day of hospitalization) (Schoenfeld et al., 2002), with a cut-off stratification point of 10 days (75th percentile) for both IMV time and for IMV free days, ventilatory weaning and severity of the disease, based on the Pediatric Risk of Mortality (PRISM IV) score values (Pollack et al., 2016).

The gasometric variables were the arterial partial pressure of oxygen $(\mathrm{PaO} 2)$, arterial partial pressure of carbon dioxide (PCO2), both in $\mathrm{mmHg}$, hydrogen potential $(\mathrm{pH})$, and sodium bicarbonate in $\mathrm{mEq} / \mathrm{L}$ (BIC). All patients used the same ventilators and ventilatory variables included were fraction of inspired oxygen (FiO2); oxygenation index (OI), oxygen saturation index (OSI); arterial oxygen saturation ( $\mathrm{SaO} 2)$ through pulse oximetry; positive end-expiratory pressure (Peep), mean airway pressure (MAP), tidal volume (TV), divided by the actual weight, in $\mathrm{ml} / \mathrm{kg}$.

The anthropometric measures used were weight in $\mathrm{kg}$ and height in $\mathrm{cm}$, with the Body Mass Index (BMI) indicators for children ( 0 to 10 years) and teenagers (over 10 years to 19 years) expressed in $\mathrm{Z}$ score according to the World Health Organization and the Brazilian Ministry of Health recommendations (WHO, 2019).

Quantitative data were expressed as absolute values and percentages, arithmetic means, and standard deviations. After applying the Shapiro-Wilk test, a bivariate analysis was initially carried out between the exposed to ARDS and the not exposed to ARDS groups, to assess the association between the exposed one and the epidemiological, gasometric, ventilatory, and clinical variables. Fisher's exact test, Wilks G test, and chi-square test were also used.

Furthermore, Poisson's logistic regression analysis was applied due to the high frequency of exposed cases. For variables selection, the variables that presented $\mathrm{p}$-value $<0.05$ were tested in the model, using bivariate analysis. The variables were considered significant if p-value $<0.05$ and $95 \% \mathrm{CI}$, and the prevalence ratio (PR) calculation was used in this model. Statistical analyzes were performed using the Minitab® 14.0 program (Minitab, LLC, Pennsylvania, USA). 


\section{Results}

There were 459 admissions to the PICU during the study period, from which $181(39,4 \%)$ medical records were included in the study. Figure 1 specifies, in a flow chart, the reasons for including and excluding medical records from the research.

Figure 1. Inclusion and exclusion criteria for medical records of patients admitted to the pediatric intensive care unit. 20162017, Belém, Pará state, Brazil. (n=181).

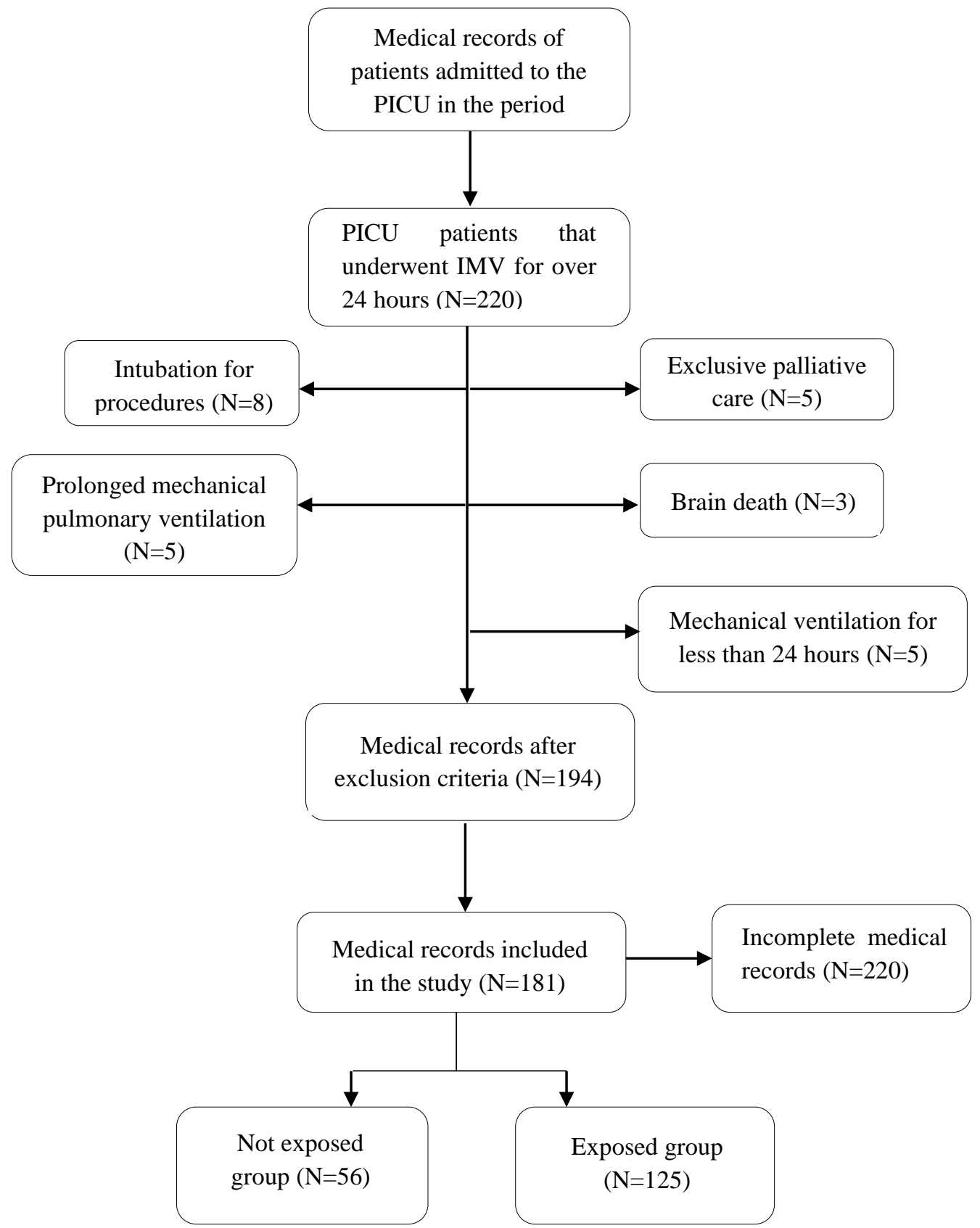

(a)PICU: Pediatric Intensive Care Unit; (b)IMV: Invasive Mechanical Ventilation. Source: Authors.

In the present study it was found that in the group exposed to ARDS there was a higher prevalence of male patients $(62.4 \%)$ and teenagers (33.7\%), however without statistical significance (p: 0.263 and p: 0.461 , respectively), as shown in Table 1. 
Table 1. Sociodemographic features of the group exposed to acute respiratory distress syndrome and the not exposed one. 2016-2017, Belém, Pará state, Brazil. (n=181).

\begin{tabular}{|c|c|c|c|c|c|c|c|}
\hline \multirow{2}{*}{$\begin{array}{c}\text { Sociodemographic features } \\
\text { Sex }\end{array}$} & \multicolumn{2}{|c|}{ Not exposed group } & \multicolumn{2}{|c|}{ Exposed group } & \multicolumn{2}{|c|}{ Population } & \multirow[b]{2}{*}{ p-value } \\
\hline & $\mathbf{N}$ & $\%$ & $\mathbf{N}$ & $\%$ & $\mathbf{N}$ & $\%$ & \\
\hline Feminin & 26 & 46,4 & 47 & 37,6 & 73 & 40,3 & \\
\hline Masculin & 30 & 53,6 & 78 & 62,4 & 108 & 59,7 & 0,263 \\
\hline Total & 56 & 100 & 125 & 100 & 181 & 100 & \\
\hline \multicolumn{8}{|l|}{ Age range } \\
\hline Infant & 12 & 21,4 & 16 & 12,8 & 28 & 15,5 & \\
\hline Preschool & 14 & 25 & 30 & 24 & 44 & 24,3 & \\
\hline Schoolchildren & 14 & 25 & 34 & 27,2 & 48 & 26,1 & \\
\hline Teenager & 16 & 28,6 & 45 & 36 & 61 & 33,7 & 0,461 \\
\hline Total & 56 & 100 & 125 & 100 & 181 & 99,6 & \\
\hline
\end{tabular}

(a) Infant: from 0 to 24 months; (b) Preschool: from 24 to 48 months; (c) Schoolchildren: from 5 to ten years of age; (d) Teenager: from 10 to 19 years of age (WHO, 2019). Source: Authors.

In the clinical variables analysis, leukemia was found to be the most frequent neoplasm in the ARDS group, corresponding to $48 \%$ of cases (p: 0.016). In the same group, most patients had pneumonia and febrile neutropenia, but differently from the expected, septic shock and multiple organ dysfunction syndrome (MODS) were absent in most of the patients with ARDS, as shown in Table 2.

Table 2. Clinical features of the group exposed to acute respiratory distress syndrome and the not exposed one. 2016-2017, Belém, Pará state, Brazil. (n=181).

\begin{tabular}{|c|c|c|c|c|c|c|c|}
\hline \multirow{2}{*}{$\begin{array}{c}\text { Clinical features } \\
\text { Neoplasm }\end{array}$} & \multicolumn{2}{|c|}{ Not exposed group } & \multicolumn{2}{|c|}{ Exposed group } & \multicolumn{2}{|c|}{ Population } & \multirow[b]{2}{*}{$\mathbf{p}$} \\
\hline & $\mathbf{N}$ & $\%$ & $\mathbf{N}$ & $\%$ & $\mathbf{N}$ & $\%$ & \\
\hline Leukemia & 16 & 28,7 & 60 & 48 & 76 & 42 & $0,016^{\mathrm{c}}$ \\
\hline $\begin{array}{l}\text { Reticulo-endothelial lymphoma and } \\
\text { neoplasms }\end{array}$ & 5 & 8,9 & 9 & 7,2 & 14 & 7,8 & \\
\hline $\begin{array}{l}\text { CNS tumors and intracranial and } \\
\text { spinal miscellaneous neoplasms }\end{array}$ & 20 & 35,7 & 19 & 15,2 & 39 & 21,5 & \\
\hline SNS tumors & 0 & 0 & 1 & 0,8 & 1 & 0,5 & \\
\hline Retinoblastoma & 1 & 1,8 & 0 & 0 & 1 & 0,5 & \\
\hline Renal tumors & 3 & 5,3 & 11 & 8,8 & 14 & 7,8 & \\
\hline Hepatic tumors & 4 & 7,1 & 7 & 5,6 & 11 & 6,1 & \\
\hline Malignant bone tumor & 1 & 1,8 & 8 & 6,4 & 9 & 5 & \\
\hline Soft tissue sarcomas & 3 & 5,3 & 2 & 1,6 & 5 & 2,8 & \\
\hline $\begin{array}{l}\text { Germ, trophoblastic and other } \\
\text { gonadal cells neoplasm }\end{array}$ & 1 & 1,8 & 6 & 4,8 & 7 & 3,9 & \\
\hline $\begin{array}{l}\text { Carcinomas and other epithelial } \\
\text { malignancies neoplasm }\end{array}$ & 1 & 1,8 & 0 & 0 & 1 & 0,5 & \\
\hline Other not specified malignant tumors & 1 & 1,8 & 2 & 1,6 & 3 & 1,6 & \\
\hline Total & 56 & 100 & 125 & 100 & 181 & 100 & \\
\hline
\end{tabular}




\begin{tabular}{|c|c|c|c|c|c|c|c|}
\hline Chemotherapy & $\mathbf{N}$ & $\%$ & $\mathbf{N}$ & $\%$ & $\mathbf{N}$ & $\%$ & $\mathbf{p}$ \\
\hline Not stablished & 12 & 21,4 & 37 & 29,6 & 49 & 27,1 & \\
\hline Stablished for less than 15 days & 24 & 42,9 & 55 & 44 & 79 & 43,6 & $0,348^{\mathrm{a}}$ \\
\hline Stalished for over 15 days & 20 & 35,7 & 33 & 26,4 & 53 & 29,3 & \\
\hline Total & 56 & 100 & 125 & 100 & 181 & 100 & \\
\hline Chemotherapy stage & $\mathbf{N}$ & $\%$ & $\mathbf{N}$ & $\%$ & $\mathbf{N}$ & $\%$ & $\mathbf{p}$ \\
\hline Maintance & 20 & 45,4 & 67 & 76,1 & 87 & 65,9 & $0,0001^{\mathrm{a}}$ \\
\hline Induction & 24 & 54,6 & 21 & 23,9 & 45 & 34,1 & \\
\hline Total & 44 & 100 & 88 & 100 & 132 & 100 & \\
\hline Associated pneumonia & $\mathbf{N}$ & $\%$ & $\mathbf{N}$ & $\%$ & $\mathbf{N}$ & $\%$ & $\mathbf{p}$ \\
\hline No & 33 & 58,9 & 52 & 41,6 & 85 & 47 & \\
\hline Yes & 23 & 41,1 & 73 & 58,4 & 96 & 53 & $0,031^{\mathrm{a}}$ \\
\hline Total & 56 & 100 & 125 & 100 & 181 & 100 & \\
\hline Sepsis & $\mathbf{N}$ & $\%$ & $\mathbf{N}$ & $\%$ & $\mathbf{N}$ & $\%$ & $\mathbf{p}$ \\
\hline Absent & 28 & 50 & 53 & 42,4 & 81 & 44,7 & \\
\hline Present & 28 & 50 & 72 & 57,6 & 100 & 55,3 & $0,342^{\mathrm{a}}$ \\
\hline Total & 56 & 100 & 125 & 100 & 181 & 100 & \\
\hline Septic shock and MODS & $\mathbf{N}$ & $\%$ & $\mathbf{N}$ & $\%$ & $\mathbf{N}$ & $\%$ & $\mathbf{p}$ \\
\hline Absent & 48 & 85,7 & 83 & 66,4 & 131 & 72,4 & $0,005^{\mathrm{b}}$ \\
\hline Present & 8 & 14,3 & 42 & 33,6 & 50 & 27,6 & \\
\hline Total & 56 & 100 & 125 & 100 & 181 & 100 & \\
\hline Associated febrile neutropenia & $\mathbf{N}$ & $\%$ & $\mathbf{N}$ & $\%$ & $\mathbf{N}$ & $\%$ & $\mathbf{p}$ \\
\hline No & 36 & 64,3 & 49 & 39,2 & 85 & 47 & \\
\hline Yes & 20 & 35,7 & 76 & 60,8 & 96 & 53 & $0,002^{\mathrm{a}}$ \\
\hline Total & 56 & 100 & 125 & 100 & 181 & 100 & \\
\hline Spent days in the PICU & $\mathbf{N}$ & $\%$ & $\mathbf{N}$ & $\%$ & $\mathbf{N}$ & $\%$ & $\mathbf{p}$ \\
\hline Less than 10 days & 45 & 80,3 & 48 & 38,4 & 93 & 51,4 & \\
\hline Over 10 days & 11 & 19,7 & 77 & 61,6 & 88 & 48,6 & $<0,0001^{\mathrm{a}}$ \\
\hline Total & 56 & 100 & 125 & 100 & 181 & 100 & \\
\hline Indication for intubation & $\mathbf{N}$ & $\%$ & $\mathbf{N}$ & $\%$ & $\mathbf{N}$ & $\%$ & $\mathbf{p}$ \\
\hline Respiratory & 20 & 35,7 & 60 & 48 & 80 & 44,2 & $0,013^{b}$ \\
\hline Hemodinamic & 16 & 28,6 & 19 & 15,2 & 35 & 19,3 & \\
\hline Neuromuscular & 7 & 12,5 & 31 & 24,8 & 38 & 21 & \\
\hline Post-operative & 13 & 23,2 & 15 & 12 & 28 & 15,5 & \\
\hline Total & 56 & 100 & 125 & 100 & 181 & 100 & \\
\hline Mechanic ventilation lenght & $\mathbf{N}$ & $\%$ & $\mathbf{N}$ & $\%$ & $\mathbf{N}$ & $\%$ & $\mathbf{p}$ \\
\hline Less than 10 days & 56 & 100 & 46 & 36,8 & 112 & 56,4 & \\
\hline Over 10 days & 0 & 0 & 79 & 63,2 & 79 & 43,6 & $<0,0001^{\mathrm{c}}$ \\
\hline Total & 56 & 100 & 125 & 100 & 181 & 100 & \\
\hline PRISM IV\% & $\mathbf{N}$ & $\%$ & $\mathbf{N}$ & $\%$ & $\mathbf{N}$ & $\%$ & $\mathbf{p}$ \\
\hline Less than 20 & 40 & 71,4 & 48 & 38,4 & 88 & 48,6 & \\
\hline Over 20 & 16 & 28,6 & 77 & 61,6 & 93 & 51,4 & $<0,0001^{\mathrm{a}}$ \\
\hline
\end{tabular}




\begin{tabular}{|c|c|c|c|c|c|c|c|}
\hline Total & 56 & 100 & 125 & 100 & 181 & 100 & \\
\hline $\begin{array}{c}\text { Days without mechanical } \\
\text { ventilation }\end{array}$ & $\mathbf{N}$ & $\%$ & $\mathbf{N}$ & $\%$ & $\mathbf{N}$ & $\%$ & $\mathbf{p}$ \\
\hline Longer than 5 days & 13 & 23,3 & 23 & 18,4 & 36 & 19,9 & \\
\hline Less than 5 days & 43 & 76,7 & 102 & 81,6 & 145 & 80,1 & $0,453^{\mathrm{a}}$ \\
\hline Total & 56 & 100 & 125 & 100 & 181 & 100 & \\
\hline 28-day mortality & $\mathbf{N}$ & $\%$ & $\mathbf{N}$ & $\%$ & $\mathbf{N}$ & $\%$ & $\mathbf{p}$ \\
\hline Survaivors & 42 & 75 & 78 & 62,4 & 120 & 66,3 & $0,097^{\mathrm{a}}$ \\
\hline Non survaivors & 14 & 25 & 47 & 37,6 & 61 & 33,7 & \\
\hline Total & 56 & 100 & 125 & 100 & 181 & 100 & \\
\hline
\end{tabular}

(a) CNS: Central nervous system; (b) SNS: Sympathetic nervous system; (c)MODS: Multiple organ dysfunction syndrome; (d) PICU: Pediatric intensive care unit; (e) PRISM IV: Pediatric Risk of Mortality Score IV. Source: Authors.

In the ARDS group, $76.1 \%$ of the patients were in the maintenance phase of chemotherapy (p: 0.0001), and its stage was considered relevant, while post-chemotherapy time did not demonstrate statistical significance. In the present study, there was still no significant difference between the two groups analyzed regarding 28-days mortality (table 2).

In the analysis of the ventilatory variables, it was found that all patients that had IMV for fewer than 10 days were part of the group diagnosed with ARDS and there was no statistically significant difference regarding the tidal volume in both groups, as shown in table 2.

Table 3 shows that $\mathrm{pH}$ had greater association both with the ARDS outcome (PR: 1.01; p: 0.043) and with the mortality outcome (PR: 1.04; p: 0.005). Table 4 shows all the gasometric parameters analyzed.

Table 3. Analysis of associated factors to acute respiratory distress syndrome and mortality. 2016-2017, Belém, Pará state, Brazil. ( $\mathrm{n}=181)$.

\begin{tabular}{|c|c|c|c|c|}
\hline Outcome & PR & CI95 & CI95 & $\mathbf{p}$ \\
\hline \multicolumn{5}{|c|}{ ARDS presence } \\
\hline OSI & 1 & 0,89 & 1,19 & 0,039 \\
\hline $\mathrm{pH}$ & 1,01 & 0,99 & 1,02 & 0,043 \\
\hline MAP & 2,17 & 1,01 & 4,65 & 0,047 \\
\hline Bone tumor & 1,32 & 0,71 & 24,6 & 0,01 \\
\hline \multicolumn{5}{|c|}{ Chemotherapy phase } \\
\hline Leucemia & 1 & 0,1 & 6,73 & 0,036 \\
\hline $\mathrm{pH}$ & 1,04 & 0,99 & 1,2 & 0,005 \\
\hline $\mathrm{PaO} 2$ & 0,99 & 0,96 & 1,02 & 0,014 \\
\hline
\end{tabular}

(a) ARDS: acute respiratory distress syndrome; (b) OSI: Oxygen saturation index; (c) $\mathrm{pH}$ : Hydrogen potential; (d) MAP: Mean airway pressure; (e) $\mathrm{PaO} 2$ : arterial partial pressure of oxygen; (f) PR: Prevalence ratio; (g) CI95 = 95\% Confidence interval. Source: Authors. 
Research, Society and Development, v. 10, n. 9, e41710917767, 2021

(CC BY 4.0) | ISSN 2525-3409 | DOI: http://dx.doi.org/10.33448/rsd-v10i9.17767

Table 4. Gasometric variables analyzed. 2016-2017, Belém, Pará state, Brazil. (n=181).

\begin{tabular}{|c|c|c|c|c|}
\hline \multirow[t]{2}{*}{ Parameter } & \multicolumn{4}{|c|}{ Mechanical ventilation patients } \\
\hline & $\begin{array}{l}\text { Not exposed group } \\
\text { (mean:CI95\%;SD) }\end{array}$ & $\begin{array}{c}\text { Exposed group } \\
\text { (mean:CI95\%;SD) }\end{array}$ & $\begin{array}{c}\text { Population } \\
\text { (mean:CI95\%;SD) }\end{array}$ & $\mathbf{p}$ \\
\hline $\mathrm{pH}$ & $7,38: 7,34-7,42 ; 0,147$ & $7,32: 7,29-7,36 ; 0,174$ & $7,34: 7,32-7,37 ; 0,168$ & $0,007^{\mathrm{d}}$ \\
\hline $\mathrm{PaO} 2$ & $\begin{array}{c}182,4: 167,2- \\
197,6 ; 56,85\end{array}$ & $\begin{array}{c}101,85: 92- \\
111,7 ; 55,62\end{array}$ & $\begin{array}{c}126,8: 116,9- \\
136,6 ; 67,18\end{array}$ & $<0,0001^{\mathrm{d}}$ \\
\hline $\mathrm{PCO} 2$ & $34,22: 31,5-36,9 ; 10,08$ & $41,6: 38,85-44,4 ; 15,54$ & $\begin{array}{l}39,31: 37,2- \\
41,44 ; 14,46\end{array}$ & $0,032^{\mathrm{d}}$ \\
\hline Bicarbonate & $22,17: 20,12-24,22 ; 7,67$ & $21,32: 19,9-22,71 ; 7,86$ & $\begin{array}{c}21,58: 20,44- \\
22,72 ; 7,79\end{array}$ & $0,496^{\mathrm{e}}$ \\
\hline $\mathrm{FiO} 2$ & $49,28: 44,1-54,34 ; 18,9$ & $79: 74-83 ; 23,8$ & $69,6: 65,8-73,3 ; 25,9$ & $<0,0001^{\mathrm{d}}$ \\
\hline Peep & $5,69: 5,4-5,97 ; 1,02$ & $7,3: 6,98-7,7 ; 1,92$ & $6,82: 6,55-7,1 ; 1,84$ & $<0,0001^{\mathrm{d}}$ \\
\hline TV & $10,84: 9,35-12,32 ; 5,54$ & $9,93: 9,06-10,8 ; 4,9$ & $10,2: 9,46-10,96 ; 5,11$ & $0,344^{\mathrm{d}}$ \\
\hline MAP & $8,73: 8,29-9,16 ; 1,61$ & $\begin{array}{c}12,17: 11,61- \\
12,73 ; 3,17\end{array}$ & $\begin{array}{l}11,1: 10,64- \\
11,57 ; 3,206\end{array}$ & $<0,0001^{\mathrm{d}}$ \\
\hline $\begin{array}{l}\mathrm{SaO} 2 \text { (mean: } \\
\mathrm{CI} 95 \% ; \mathrm{SD})\end{array}$ & $97,4: 94,5-100 ; 10,7$ & $93,1: 91,2-94,5 ; 8,67$ & $94,1: 92,8-95,5 ; 9,48$ & $<0,0001^{\mathrm{d}}$ \\
\hline PRISM IV\% & $20,8: 14,64-26,9 ; 22,89$ & $31,6: 27,1-36,2: 25,7$ & $\begin{array}{c}28,23: 24,51- \\
31,94 ; 25,3\end{array}$ & $0,005^{\mathrm{d}}$ \\
\hline OSI & $4,73: 3,48-5,98 ; 4,68$ & $10,82: 9,87-11,77 ; 5,36$ & $8,93: 8,1-9,8 ; 5,87$ & $<0,0001^{\mathrm{d}}$ \\
\hline OI & $2,34: 2,13-2,55 ; 0,782$ & $\begin{array}{c}12,55: 10,88- \\
14,21 ; 9,38\end{array}$ & $9,4: 8,05-10,73 ; 9,12$ & $<0,0001^{\mathrm{d}}$ \\
\hline
\end{tabular}

(a) pH: Hydrogen potential; (b) PaO2: Arterial partial pressure of oxygen; (c) PCO2: Arterial partial pressure of carbon dioxide; (d) FiO2: Fraction of inspired oxygen; (e) Peep: Positive end-expiratory pressure; (f) TV: Tidal volume; (g) MAP: Mean airway pressure; (h) SaO2: Arterial oxygen saturation; (i) CI95\%: 95\% Confidence interval; (j) SD: Standard derivation; (k) PRISM IV: Pediatric Risk of Mortality Score IV; (l) OSI: Oxygen saturation index; (m) OI: Oxygen index; (f) PR: Prevalence ratio; (g) CI95 = 95\% Confidence interval. Source: Authors. 


\section{Discussion}

Acute respiratory distress syndrome, considered a major cause of morbidity and mortality among critically ill patients, had an incidence of $69.06 \%$ in the present study. In the general pediatric population, an incidence of ARDS between 2-12.8 per 100,000 person-years has been demonstrated (Rowan et al., 2017). In 2019, Pillon et al (2019) found that a third of the patients with criteria for acute respiratory distress syndrome requiring invasive mechanical ventilation or non-invasive ventilation, a similar result to that found in the present study, both of which were performed in oncohematological children in PICUs without previous bone marrow transplant.

Many research shows that immunodeficiency is a pre-existing condition and also a risk factor for mortality in ARDS (Thomas et al., 2018). Studies of the disease highlight differences in survival rates among immunosuppressed children when compared to immunocompetent children, with mortality rates of up to $60 \%$ in the population with compromised immune system (Nina et al., 2018)

High morbidity and mortality, associated with the lack of research in this population, and the peculiarities of the Amazon population - a region with low resources and a late diagnosis for cancer (Khemani et al., 2015) -, reinforces the relevance of developing such studies, as the present one, a pioneer in addressing the issue in the Northern region of the country.

In the present study, there was no statistical difference in the mortality outcome from the group of exposed patients to the one not exposed to ARDS. Pillon et al (2019) showed in their study neither the respiratory failure nor its severity on admission or during the PICU hospitalization period had a significant impact on 90-days mortality, differently from the data found in other cohorts studies with cancer patients (Thomas et al., 2018).

In the present study, leukemia was the most related to respiratory distress syndrome type of cancer, agreeing with Pillon et al (2019), who found the same type of cancer in 59\% of PICU admissions, probably because it is the most prevalent one in childhood (Macêdo et al., 2014).

Most patients with ARDS in the study were in the maintenance phase of chemotherapy. Although this phase is the period in which patients have larger clinic stability, children who receive cancer treatment may present lung toxicity as a result of chemotherapy or associated with radiotherapy, from the initial phase to several months after treatment (Elbahlawan et al., 2011). Several factors predispose cancer patients to lung injury, including chemotherapy-induced lung toxicity, as well as an increased risk to pneumonia and sepsis secondary to immunosuppression and myelosuppression (Fuchs et al., 2017).

A large number of pediatric cancer patients who require invasive mechanical ventilation are neutropenic at the moment respiratory failure develops ((Fuchs et al., 2017), which corroborates to the present study, that has found that most patients with ARDS also had febrile neutropenia.

Pillon et al (2019) found, in their study, pulmonary causes as the main indication for admission to the PICU, usually due to acute respiratory failure and largely due to infection. That study corroborates with the present one, in which pneumonia was present in most patients who needed IMV and had acute respiratory distress syndrome.

The findings in the present study showed septic shock was not related to the presence of ARDS, unlike other studies, such as Pillon et al in 2019, that showed a 40\% prevalence of this type of shock at the time of admission. However, as showed in that study in and the present one, there was no statistical significance of this factor as a mortality predictor.

Unlike the study developed by Pillon et al (2019), in which half of the patients already had multiple organ failures on admission and it was relevant to the mortality outcome, in our study there was no such statistical significance between the two analyzed groups. Furthermore, MODS is the most important independent clinical risk factor for mortality in children with ARDS (Azoulay et al., 2010). 
Rowan et al in 2017 pointed to a mortality rate around 60\% among bone marrow transplant patients who required mechanical ventilation for an average of 10 days and also showed that even in the beginning of IMV, both survivors and nonsurvivors had high peak pressures, as well as a median initial OI of almost 12 in both groups (Pillon et al., 2019). In the present study, probably all patients with mechanical ventilation for less than 10 days were in the ARDS group due to the severity of the disease, which may have led to earlier deaths and fewer days free from IMV, in agreement with Rowan et al in 2017, that showed that cases of moderate and severe ARDS had fewer days free of mechanical ventilation, as well as longer length of stay in PICU. The clinical severity of this group of patients must also be taken into account since studies point to high mortality in the first 48 hours even in the absence of ARDS (Thomas et al., 2018).

Current guidelines recommend the concept of low tidal volume and permissive hypercapnia ventilation for patients with sepsis, ARDS, or chronic respiratory failure. In several models, hypercapnic acidosis has been associated with benefits to lung and distant organ and in the reduction of ventilation parameters with reduction of lung injuries, in the release of cytokines, the formation of pulmonary edema, and histological lesions (Elbahlawan, Srinivasan, Morrison, 2016).

Studies point out mortality reduction from $40 \%$ to $31 \%$ with $6 \mathrm{ml} / \mathrm{kg}$ tidal volume for ideal weight, compared when used $12 \mathrm{ml} / \mathrm{kg}$ for ideal weight (Rowan et al., 2012). In the present study, there was no statistical difference regarding tidal volume in both groups probably due to the fact that most children in the oncology service analyzed are ventilated under pressure, providing more variable tidal volume. In the study performed by Rowan et al (2012), there was no significant difference between the group of surviving and non-surviving ARDS patients (Fuchs et al., 2015). Furthermore, among gasometric variables, $\mathrm{pH}$ showed a greater association both with ARDS and with the mortality outcome, differently from evidence in the study by Fuchs (2015).

There are limitations that must be considered in the study, such as its retrospective approach and reliance on the data available on the medical data sourse used in the study, which was minimized by the exclusion of incomplete data and its valitadion process to start the research.

\section{Conclusion}

The incidence of undergoing IMV in ARDS patients was $69.06 \%$ and potential associated risk factors were: intubation due to respiratory disease, presence of pneumonia, as well as febrile neutropenia and chemotherapy maintenance phase. There was a greater association of $\mathrm{pH}$ with the mortality outcome among patients with ARDS.

These data are important since it is one of the first studies carried out on ARDS in the pediatric cancer population in the North of Brazil, comprehending Brazilian Amazon, but more research is needed to better correlate risk factors and ARDS in the pediatric cancer population, taking into account the limitations of this research.

\section{Acknowledgments}

To the Children's Oncologic Hospital Octávio Lobo and its team, which serves thousands of children in Pará as well as the Northern region of Brazil, saving many lives.

\section{References}

ANVISA, Agência Nacional de Vigilância Sanitária. Caderno 2 -Critérios Diagnósticos de Infecções Relacionadas a Assistência à Saúde (2017). Brasília-DF, 2017. (2a ed.), https://www20.anvisa.gov.br/segurancadopaciente/index.php/publicacoes/item/criteriosdiagnosticos-das-infeccoes-relacionadas-a-assistencia-asaude

Azoulay, É., Mokart, D., Lambert, J., Lemiale, V., Rabbat, A., Kouatchet, A., \& Schlemmer, B. (2010). Diagnostic strategy for hematology and oncology patients with acute respiratory failure: randomized controlled trial. American journal of respiratory and critical care medicine, $182(8), 1038-1046$. 
Baden, L. R., Swaminathan, S., Angarone, M., Blouin, G., Camins, B. C., Casper, C., \& Smith, C. (2016). Prevention and treatment of cancer-related infections, version 2.2016, NCCN clinical practice guidelines in oncology. Journal of the National Comprehensive Cancer Network, 14(7), 882-913.

Beringer, N., Poole, J. E., Ballot, D. E., \& Geel, J. A. (2017). Appropriateness of admissions of children with cancer to intensive care facilities in a resourcelimited setting. SA Journal of Oncology, 1(1), 1-7.

Brasil. Ministério da Saúde. Secretaria de Atenção à Saúde. Departamento de Atenção Básica (2012). Saúde da criança: crescimento e desenvolvimento / Ministério da Saúde. Secretaria de Atenção à Saúde. Departamento de Atenção Básica. - Brasília: Ministério da Saúde, 2012. 272 p.: il. - (Cadernos de Atenção Básica, $\left.n^{\circ} 33\right)$.

Elbahlawan, L., Srinivasan, A., \& Morrison, R. R. (2016). A critical care and transplantation-based approach to acute respiratory failure after hematopoietic stem cell transplantation in children. Biology of Blood and Marrow Transplantation, 22(4), 617-626.

Elbahlawan, L. M., Morrison, R. R., Jeha, S., Cheng, C., Liu, W., \& Fiser, R. T. (2011). Impact of neutrophil recovery on oxygenation in pediatric oncology patients with acute hypoxemic respiratory failure. Journal of pediatric hematology/oncology, 33(7), e296-e299.

Fuchs, H., Rossmann, N., Schmid, M. B., Hoenig, M., Thome, U., Mayer, B., \& Hummler, H. D. (2017). Permissive hypercapnia for severe acute respiratory distress syndrome in immunocompromised children: A single center experience. PloS one, 12(6), e0179974.

Goldstein, B., Giroir, B., \& Randolph, A. (2005). International pediatric sepsis consensus conference: definitions for sepsis and organ dysfunction in pediatrics. Pediatric critical care medicine, 6(1), 2-8.

Khemani, R. G., Smith, L. S., Zimmerman, J. J., Erickson, S., \& Pediatric Acute Lung Injury Consensus Conference Group. (2015). Pediatric acute respiratory distress syndrome: definition, incidence, and epidemiology: proceedings from the Pediatric Acute Lung Injury Consensus Conference. Pediatric Critical Care Medicine, 16(5_suppl), S23-S40.

Macêdo, T. M. F. D., Campos, T. F., Mendes, R. E. D. F., França, D. C., Chaves, G. S. D. S., \& Mendonça, K. M. P. P. D. (2014). Pulmonary function of children with acute leukemia in maintenance phase of chemotherapy 尔. Revista Paulista de Pediatria, 32, 320-325.

Nina G, N. M., \& Sardinas C, S. (2018). Induction outcomes in children with acute lymphoblastic leukemia in the hospital del niño" Ovidio Aliaga Uria", period 2013-2015: case series. Cuadernos Hospital de Clínicas, 59, 17.

Rowan, C. M., Hege, K. M., Speicher, R. H., Goodman, M., Perkins, S. M., Slaven, J. E., \& Nitu, M. E. (2012). Oxygenation index predicts mortality in pediatric stem cell transplant recipients requiring mechanical ventilation. Pediatric transplantation, 16(6), 645-650.

Pereira, A. S. et al. (2018). Metodologia da pesquisa cientifica. UFSM. https://repositorio.ufsm.br/bitstream/handle/1/15824/Lic_Computacao_MetodologiaPesquisa-Cientifica.pdf?sequence $=1$.

Pillon, M., Sperotto, F., Zattarin, E., Cattelan, M., Carraro, E., Contin, A. E., \& Amigoni, A. (2019). Predictors of mortality after admission to pediatric intensive care unit in oncohematologic patients without history of hematopoietic stem cell transplantation: A single-center experience. Pediatric blood \& cancer, 66(10), e27892.17.

Pollack, M. M., Holubkov, R., Funai, T., Dean, J. M., Berger, J. T., Wessel, D. L., \& Eunice Kennedy Shriver National Institute of Child Health and Human Development Collaborative Pediatric Critical Care Research Network. (2016). The pediatric risk of mortality score: update 2015. Pediatric critical care medicine: a journal of the Society of Critical Care Medicine and the World Federation of Pediatric Intensive and Critical Care Societies, 17(1), 2.

Rowan, C. M., Smith, L. S., Loomis, A., McArthur, J., Gertz, S. J., Fitzgerald, J. C., \& Cheifetz, I. M. (2017). Pediatric acute respiratory distress syndrome in pediatric allogeneic hematopoietic stem cell transplants: a multicenter study. Pediatric critical care medicine, 18(4), 304-309.

Steliarova-Foucher, E., Stiller, C., Lacour, B., \& Kaatsch, P. (2005). International classification of childhood cancer. Cancer, 103(7), $1457-1467$.

Schoenfeld, D. A., \& Bernard, G. R. (2002). Statistical evaluation of ventilator-free days as an efficacy measure in clinical trials of treatments for acute respiratory distress syndrome. Critical care medicine, 30(8), 1772-1777.

Su, X., Bai, C., Hong, Q., Zhu, D., He, L., Wu, J., \& Matthay, M. A. (2003). Effect of continuous hemofiltration on hemodynamics, lung inflammation and pulmonary edema in a canine model of acute lung injury. Intensive care medicine, 29(11), 2034-2042.

Tamburro, R. F., Barfield, R. C., Shaffer, M. L., Rajasekaran, S., Woodard, P., Morrison, R. R., \& Sillos, E. M. (2008). Changes in outcomes (1996-2004) for pediatric oncology and hematopoietic stem cell transplant patients requiring invasive mechanical ventilation. Pediatric Critical Care Medicine, 9(3), $270-277$.

Thomas, N. J., Spear, D., Wasserman, E., Pon, S., Markovitz, B., Singh, A. R., \& Pediatric Acute Lung Injury and Sepsis Investigators Network. (2018). CALIPSO: a randomized controlled trial of calfactant for acute lung injury in pediatric stem cell and oncology patients. Biology of Blood and Marrow Transplantation, 24(12), 2479-2486.

WHO Multicentre Growth Reference Study Group (2019). WHO Child Growth Standards: Methods and Development. Length/height-forage, weightfor-age, weight-for-length, weight-for-height and body mass index-for age: methods and development. http://www.who.int/child growth/standards/technical_report/en/index.html. Acesso em 10 de setembro de 2019.

Zinter, M. S., Dvorak, C. C., Mayday, M. Y., Iwanaga, K., Ly, N. P., McGarry, M. E., \& DeRisi, J. L. (2019). Pulmonary metagenomic sequencing suggests missed infections in immunocompromised children. Clinical Infectious Diseases, 68(11), 1847-1855. 